\title{
Bolivian Oil and Natural Gas under State and Private Control, 1920-2010 ${ }^{1}$
}

\author{
Herbert S. Klein \\ Stanford University and Columbia University \\ José Alejandro Peres-Cajías \\ Escuela de la Producción y la Competitividad, \\ Universidad Católica Boliviana
}

\begin{abstract}
Since the 1920 discovery of oil in Bolivia, the country has experimented with varying systems of private control, monopoly state ownership and even mixed state and private ownership/rental of petroleum and gas fields. The aim of our analysis is to explain why these varying patterns of ownership occurred over time and to describe how they affected production in this industry. The analysis suggests that nationalizations have been successful insofar as they took advantage of previous private investment which, meanwhile, underscores the success of the legislation for opening up access
\end{abstract}

\footnotetext{
${ }^{1}$ An earlier version of this paper has been presented at the Session "Varieties of Capitalism: the State and Business in Emerging Markets, 1930s-1990s" at the XVI World Economic History Association Congress held in Stellenbosch (South Africa, July 2012). We appreciate all the comments and suggestions made by participants at that event. Peres-Cajías has benefited from financial support from the University of Barcelona through the APIF (2008-2012) fellowship program; from the Science and Innovation Ministry of Spain through the project ECO2009-13331-C02-02; and from the Catalonian Research and Universities Grant Agency through the BE-DGR 2011 fellowship program. Usual disclaimer applies.
} 
to attract private investment. This relative success of the different legal frameworks permits us to understand why the state has been changing from one scheme to another over time. Some partial explanations are offered in order to understand why these schemes could succeed with such regularity.

\section{Keywords}

Bolivian oil, nationalization, oil and gas

\section{Resumen}

Desde el descubrimiento del petróleo en Bolivia en el año 1920, el país ha experimentado con una variedad de sistemas de control privado, de propiedad monopólica estatal e incluso con la propiedad o el alquiler de campos petroleros y de gas en manos privadas. El propósito de nuestro análisis es explicar por qué se han dado estos variados modelos de propiedad y describir cómo han afectado en la producción de esta industria. El análisis sugiere que las nacionalizaciones han sido exitosas en la medida en que tomaron ventaja de una inversión privada anterior, lo cual mientras tanto resalta el éxito de la legislación de "apertura" para atraer la inversión privada. El éxito relativo de los diferentes marcos legales nos permite comprender por qué el estado ha ido cambiando de un esquema a otro con el paso del tiempo. Se ofrecen algunas explicaciones parciales para entender por qué este esquema pudo dar resultado con tanta regularidad.

Palabras claves

nacionalización, petróleo boliviano, petróleo y gas

Although Bolivia is a relatively small producer of oil and gas by world standards, petroleum and especially natural gas have become a fundamental part of the national economy and have accounted for the major share of exports and government revenues throughout the last decades. Since the 1920 discovery of oil, the nation has experimented with varying systems of private control, monopoly state ownership and even mixed state and private ownership/rental of petroleum and gas fields. Initially, the state typically granted rights to extract these resources to private companies with the proviso that these concessions were relatively limited in time and could be revoked for failure to exploit the given resource. This policy changed in the 1930s with the beginnings of state controlled enterprises which produced 
oil and gas as both a competitor to the private producers or as monopolists who took control of the concessions and facilities of private producers.

The aim of our analysis will be to explain why these varying patterns of ownership occurred over time and to describe how these differing regimes affected production in this industry. We will also examine the changing importance of taxation of this crucial industry and its impact on government finance and investment as well as the role of national and international markets and how these exogenous factors affected ideas about ownership, government income and petroleum and gas imports and exports.

\section{The growing importance of hydrocarbons}

The beginnings of the oil industry in Bolivia go back to the late nineteenth and early twentieth centuries. Despite this early start, it was not until 1925 that actual extraction of oil began (fig. 1). Initial production levels were extremely low and averaged just 30 thousand barrels per year until 1932. But due to the demands generated by the Chaco War (1932-1935), those levels began to expand. This upward trend continued more or less uninterrupted until the late 1940s. Then, production stabilized at around 600 thousand barrels per year. Despite the increase, production was still small.

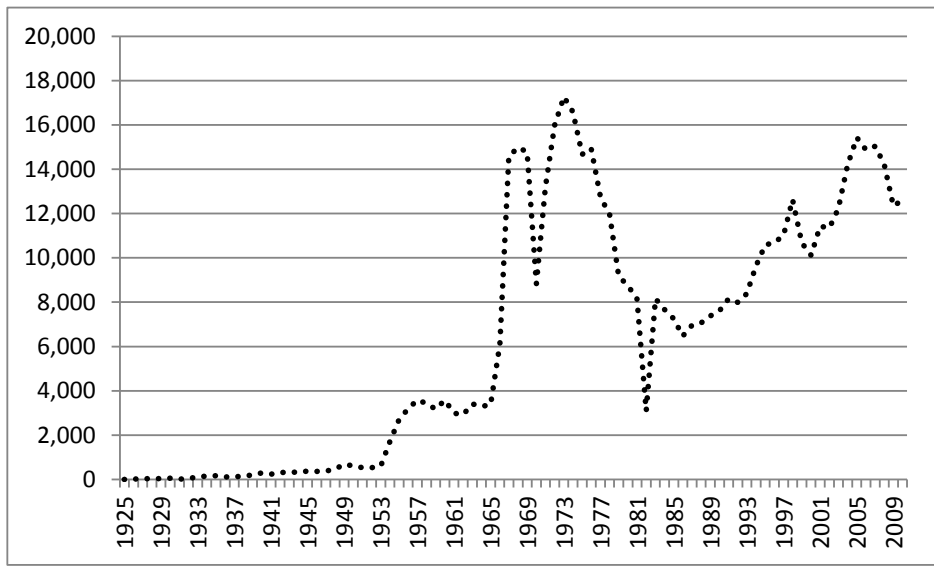

Figure 1: Production of oil in Bolivia in thousands of barrels per year, 1925-2010

Sources: Own elaboration based on Royuela (1996: 230-31), for years 1965-95; and from INE, "Índice de cantidad de extracción," in

Estadísticas Petroleras, for years 1996-2010 [www.ine.gob.bo] 
In 1954, oil production tripled the volume reached a year earlier and the country achieved self-sufficiency. This increase would receive a new impulse around 1967, when annual production reached 14 million barrels. Apart from some fluctuations, it was stable at around this level until 1976 the best years for oil production in Bolivia. However, it declined in the late 1970s and only in the early 1990s did a slow recovery occur, but even to this day Bolivia has not exceeded the levels achieved in the first half of the 1970s.

Given that natural gas was found in the same fields as oil, its existence was well known from the earliest oil explorations, but its economic importance did not begin until major foreign markets were opened up. Indeed, whereas the first records of natural gas production go back to 1952, it was not until 1972, with the start of exports to Argentina, that production reached significant levels (fig. 2). After this initial jump, production levels tended to stagnate. This level of activity lasted almost until the end of the twentieth century. From 2000 onward, however, thanks to exports to Brazil, the levels of natural gas production increased once again. Thus, in contrast to oil, natural gas production has maintained an upward trend of production over the long term.

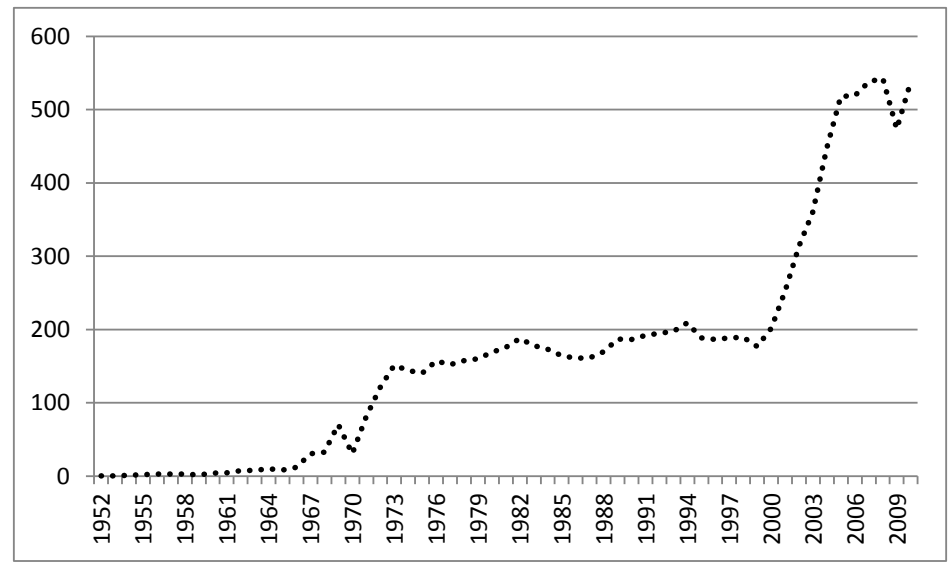

Figure 2: Production of natural gas in billions of cubic feet per year, 1952-2010

Sources: Own elaboration based on INE (1997), for years 1952-94; and from INE, "Producción Bruta de Gas Natural” for years 1995-2010 [www.ine.gob.bo] 
Natural gas production has emerged not only as the single most important product of hydrocarbon activity in Bolivia, but has become one of the most influential industries in the national economy. This process can be seen in the weight of the hydrocarbon sector within the total GDP of Bolivia. Between 1925 and 1953 the oil sector was less than 1\% of Bolivia's total GDP. In 1954 the industry began to advance in terms of its relative importance and by the mid-1960s it reached around 1\% of national GDP. But since 1972, the relative importance of the sector has become ever more significant, reaching between $4 \%$ and $7 \%$ of Bolivia's GDP. ${ }^{2}$

The growing importance of the hydrocarbon sector was accompanied by a change in the composition of Bolivian exports. Indeed, until the early 1970s, mining exports represented at least $80 \%$ of the value of Bolivian exports. At that time, hydrocarbons came to constitute around a third of Bolivia's exports. The ratio increased up to $50 \%$ in the early years of the 1980 s, thanks to both the crisis in mining and the maintaining of oil and gas exports. In the late 1980s and throughout the 1990s, with government promotion of the socalled non-traditional exports, the relative importance of mining and oil and gas exports was reduced. However, since 2000, oil and gas exports have again risen to about $50 \%$ of total exports. ${ }^{3}$

Hydrocarbons have become essential also by their centrality to the state's finances. Until the 1970s, tax revenues generated by imports or obtained directly in the mining sector, were on average two thirds of the Bolivian Central Treasury revenue. By contrast, taxes generated directly by the hydrocarbon sector were insignificant. However, because of changes in national legislation and the start of natural gas exports to Argentina, oil and gas taxes started to become increasingly important. Despite some variability, these taxes represented $20 \%$ of Central Treasury revenues from the early 1970 's to 1985 . With the crisis in mining and the beginning of the New Economic Policy (1985), hydrocarbon taxation became even more significant, amounting to almost half of the income of Bolivian governments. This tended to decrease over time, stabilizing at around $25 \%$ of general government revenue. In recent years, the centrality of hydrocarbon taxation has increased

\footnotetext{
2 For the relative importance of the sector in the Bolivian GDP, see Herranz-Loncán and Peres-Cajías (2013), for years 1925-1949; Naciones Unidas (1958: 15) for years 1950-1955; INE (1997: 3-5) for years 1958-1979; Dossier Estadístico UDAPE, for years 1980-2010.

3 For relative importance of mining on exports, see: Gómez (1978), for years 1950-1969; for relative importance of oil and gas, see: INE (1997: 6-8), for years for 1950-1969; see CEPALSTAT, for years 19702008.
}

Bolivian Studies Journal /Revista de Estudios Bolivianos

http://bsj.pitt.edu

Vol. 20 • 2014 • doi: 10.5195/bsj.2014.97 • ISSN 1074-2247 (print) • ISSN 2156-5163 (online) 
again, representing, on average, one third of total government revenues (Peres-Cajías, 2013).

Thus, production of oil and natural gas has become essential to the Bolivian economy. The hydrocarbon sector has been gaining importance since the mid-twentieth century and today represents $7 \%$ of GDP, half of Bolivia's exports and one third of central government revenue. The evolution of these three indicators reflects in part a continuous change in the management of hydrocarbons. However, at the same time, it allows us to understand the significance of these changes. The following sections will detail the milestones reached in these management changes, and an evaluation of how they have affected the evolution of key industry variables.

\section{The evolution of legal changes in the hydrocarbons sector}

Already by the end of the nineteenth century, the Bolivian government was aware of the existence of oil deposits in the eastern lowlands. In the 1880 s and 1890 s oil deposits were discovered by national and foreign geologists and explorers in Bolivia's largely uninhabited eastern lowlands (López, 1922: 181; Loza, 1939: 4-5). These geological finds were soon followed by the formation of numerous Bolivian-financed companies that received liberal land concessions by governments eager to exploit this great source of wealth. But Bolivian capital was insufficient to develop the industry and so speculation in these petroleum land concessions rather than active exploitation of deposits became the primary aim of those national firms (Almaraz, 1958: 69-70). The only serious exploitation effort made at that time was undertaken by the Bolivian Luis Lavadenz, who organized his Sindicato de Oriente Boliviano in 1912. Lavadenz succeeded in carrying out initial survey work, but was forced to seek European capital for full exploitation. After some failed trials with both Percival Farquhar and Royal Dutch Shell, he secured Chilean support and in 1916 formed a Chilean-Bolivian company to exploit his concessions (Schurz, 1921: 138-139).

In this same year, the government attempted to reorganize its overly liberal and chaotic concessions policy and in December, 1916, issued a petroleum law which provided for both taxing and tighter regulations on existing concessions. From 1916 to 1920, local Chilean and Anglo-Bolivian capital was invested in Bolivian petroleum concessions, reorganizing the pre1916 grants into larger holdings, but without any concessionaire actually 
beginning production. Because of this, the Bolivian government in 1920 again opened up the oil-rich lands for new concession grants. Both the Richmond Levering Company of New York and William Braden and his son Spruille quickly stood out among these producers (Schurz, 1921: 139-140; Almaraz, 1958: 74-75).

Shortly after, however, the giant Standard Oil Company of New Jersey began to acquire the Levering and Braden holdings, and in late 1921 the parent New Jersey firm officially created the Standard Oil Company of Bolivia to develop these holdings. ${ }^{4}$ Meanwhile, the new Republican Party regime of Bautista Saavedra (1920-1925) enacted a new Petroleum Code in 1921 which proclaimed the fundamental proposition of state ownership of subsoil petroleum holdings, and provided new restrictions on government granted concessions.

Standard Oil began to explore and produce petroleum in Bolivia by 1925 , when it had established eleven work camps and was already producing an average of 71 barrels of oil per day from its several successful wells by $1927 .{ }^{5}$ Whereas production remained constant until the eve of the Chaco War, the threat of war with Paraguay caused the company to begin dismantling much of its equipment and shipping it out of the country (Montenegro, 1938: 54).

Before long, the leftist intellectuals of the continent began charging that the war was not really a conflict between Bolivia and Paraguay, but between the American Standard Oil Company and the British Royal Dutch Shell (which held Paraguayan holdings) for the possession of the Chaco oil (see e.g. Marof, 1934: 147ff; Colle, 1935: 105ff; Setaro, 1936: 23ff). While this allegation was impossible to prove, the constant defeats suffered by Bolivia caused extreme cynicism over the motives of the Bolivian government in causing the war and universal condemnation of Standard. This charge was coupled with the definitely uncooperative attitude shown toward the nation by the company

\footnotetext{
${ }^{4}$ The Standard Oil Company of Bolivia was founded in the United States in November, 1921, with a capitalization of $\$ 5,000,000$ (New York Times, November 15, 1921), and was incorporated in La Paz a short time later (New York Times, December 3, 1921). In March, 1921, the Richmond Levering Company finally sold its concessions in New York to Standard Oil, and the Company purchased Braden's concessions later that year.

${ }^{5}$ While both government sources and later company statements and internal records admitted that production of some quantities of oil had begun at the Standard Oil wells as early as 1925, the Standard Oil Company of Bolivia throughout the 1920's maintained that it was producing absolutely no oil. Thus, the Company officially declared to the Bolivian government that it still "had not begun the production of petroleum" from its wells, and would therefore not pay the new tax exploitation schedule. See Muñoz Reyes (1937: 2-5) and Montenegro (1938: 35).
}

Bolivian Studies Journal /Revista de Estudios Bolivianos

http://bsj.pitt.edu

Vol. 20 • 2014 • doi: 10.5195/bsj.2014.97 • ISSN 1074-2247 (print) • ISSN 2156-5163 (online) 
during the conflict. ${ }^{6}$ Hence, by the close of the war, there was almost universal hostility expressed against the company because of all of these factors.

After the war, on December 21, 1936, the Bolivian government led by David Toro created Yacimientos Petroliferos Fiscales Bolivianos (YPFB). The YPFB was established as an exclusively government-owned, autonomous corporation directly dependent on the President. ${ }^{7}$ It was given the right to explore and exploit all lands granted to it by the government and to develop, refine, transport, and market petroleum and its derivatives throughout the Republic. Aside from freedom from taxation and import duties, the new company was given power to enter into partnership in mixed companies with private capital to develop national petroleum resources if it so desired. On January 16, 1937, YPFB was assigned its petroleum concession lands, which pertained to almost all of the known petroleum areas save those in the hands of Standard Oil. Thereafter, on March 13, 1937, the government announced that it was confiscating the Standard Oil Company of Bolivia for violation of its contract and for defrauding the government treasury.

Bolivia not only obtained support from the National Supreme Court which validated its confiscation, but it also signed a series of treaties with neighboring Argentina and Brazil whereby the three nations officially acknowledged de jure and de facto Bolivian control over the old Standard Oil Company fields and equipment (Loza, 1939: 129-146). Meanwhile YPFB was able to expand national oil production in a major way without new investment, since the Standard Oil wells had largely been under-producing or shut off in 1937 (Almaraz, 1958: 135-137; Naciones Unidas, 1958: 192-193).

For its part Standard got backing from the U. S. State Department, which refused all Bolivian requests for aid while the issue of compensation was unsettled. But the coming of World War II and the US need of Bolivian

\footnotetext{
${ }^{6}$ For instance, the company transferred large amounts of its equipment to Argentina, and despite constant government requests refused to refine aviation gasoline at its Bolivian plants, claiming technical incapacity to do so. In desperation, the government in 1933 seized the refineries and under government technicians' supervision aviation gasoline was successfully produced for the Bolivian army. See Montenegro (1938: 54); Loza (1939: 120-121).

${ }^{7}$ The preamble to the YPFB decree justified its creation by declaring "that Bolivia, having rich and extensive deposits of hydrocarbons, this wealth up to the present time has not begun to strengthen the national economy in the form and proportion to which it should." To resolve this problem, the best method available, added the preamble, would be for the state to directly enter the field in its own right to develop the nation's petroleum resources.
} 
raw materials forced a change in State Department thinking. Thus, given the collapse of Standard's united front with the State Department, and the consistency in Bolivian government policy under both radical and conservative governments alike, the company soon began to shift its position. Having already written off the Bolivian oil resources, and faced by the far greater Mexican confiscation issue, by late 1941 the company expressed its willingness to accept a definitive settlement. The Bolivian government's response was rapid, and on January 27,1942 , it signed an agreement with the Company finally settling the entire issue.

During the 1940s, while the legislation provided that YPFB could be associated with any business, either for fear of expropriation or lack of interest, no other company invested in the country and, therefore, YPFB enjoyed a "de facto monopoly." After the nationalist Revolution of April 1952 and thanks to the Movimiento Nacionalista Revolucionario (MNR) government's political will, investments in the petroleum sector increased by transferring funds from the mining sector, and with this, oil production rose (Zondag, 1966). Nonetheless, this investment scheme was unsustainable and the country soon found that it could not provide the heavy capital investment the industry needed for basic expansion. Thus, once again, it invited American oil companies to invest by decreeing a new petroleum law - commonly known as the Código Davenport - which opened up Bolivia's oil fields to private oil companies. ${ }^{8}$

While Standard Oil refused this offer to return, other major North American companies did not hesitate, including the third largest oil company globally at the time, Gulf Oil Co. Although the terms of the old relationship between foreign companies and the national government were now somewhat modified, the friction still had not been fully eliminated and many of the same problems of contrasting viewpoints continued to exist. Specifically, once natural gas began to be exploited in oil fields, tensions arose between the government and the Bolivian Gulf Oil Co. (BOGOC) regarding the transparency of the company and the tax dollars generated. Things worsened in 1967, once BOGOC unilaterally signed a contract to sell gas for 20 years

\footnotetext{
${ }^{8}$ This change must be understood in the broader context of the Stabilization Plan of 1956 implemented by the Bolivian Government following the IMF and US Government's advice. According to the leftist wing of the MNR and the popular movement which made the revolution possible, this change in the political economy as well as the stipulation of the Código Davenport - betrayed the principles of the Revolution. So, not surprisingly, these measures reduced political support for the government. However, these measures could be sustained over time thanks to their ability to control the serious macroeconomic imbalances brought on by the Revolution and thanks to constant (and massive) US Government support (see Zondag, 1966).
} 
to the State Gas Company of Argentina (Gas del Estado de Argentina) and formed the company "Bolsur" with William Brothers \& Co. to build a new pipeline to Argentina (Miranda, 1999: 252-253).

Given these increasing tensions, the military government of General Alfredo Ovando Candia - which can be narrowly defined as nationalistic and left-wing oriented - decided to abrogate the Código Davenport in October of 1969 and nationalize Gulf Oil's Bolivian holdings. This second nationalization initially resulted in a temporary embargo that led to a reduction in domestic oil production. Soon after, however, the country reached an agreement with the company and oil and gas production increased. Moreover, the eruption of a new military government in August of 1971 - this time right-wing oriented implied the need for the drawing up of a new Hydrocarbons Law (1972) which clearly maintained the state-owned property on both oil and gas fields, but allowed the signing of contracts between YPFB and private companies.

More legal modifications took place in the context of a fiscally exhausted economy by way of the external debt crisis and the implementation of the Washington Consensus guidelines throughout Latin America. Indeed, the Hydrocarbons Law of 1990, which was enacted in order to attract foreign investment, was replaced by a more aggressive law a few years later (1996) (see Grebe and Chávez, 1998). This law, which was implemented through the so-called "capitalization" process, allowed some of the world industry's largest companies to increase their investments in the country. This resulted in the temporary increase in oil wells and oil production, but above all, increased levels of natural gas production. Thus, the rise in the importance of the gas-based economy is without doubt related to the provisions of the Hydrocarbons Law of 1996 (Capra et al., 2005).

Meanwhile, however, there was a widespread perception among the population that it was the foreign private companies and not Bolivians who ended up benefiting from this expansion in natural gas production (Delegación Presidencial para la Revisión y Mejora de la Capitalización, 2004). Moreover, this perception was slowly translated into a new political slogan the need to recover the country's natural resources - that allowed several political groups to unify against the political-economic policies implemented in Bolivia since the late 1980s. This new political context led to the overthrow of Gonzalo Sánchez's government (2003) and the implementation of a new Hydrocarbons Law (2005). Furthermore, one of the first measures executed by Evo Morales' administration - one which explicitly rejects the Washington 
Consensus paradigm - consisted in the nationalization of the oil and gasproducing fields (2006).

Thus, since the early-2000s, a new episode of greater state intervention in the hydrocarbon sector took place. This process recovered YPFB's previous importance but did not eliminate foreign companies; instead, it modified their contracts in major ways and considerably increased state royalties on their production. The result was the odd pattern of involvement established by foreign companies, especially the state-owned Petrobras, of remaining in the country as producers, though obviously reducing their investments over time. $^{9}$

\section{How changing regulations affected the industry}

The purpose of this section is to understand how the aforementioned changes in ownership and management of oil described in the previous section affected the evolution of different key industry variables. The first variable analyzed is the opening of wells in production by producer type (public or private). The analysis of the number of wells in production represents an approach to understanding the level of investment by oil companies. This variable represents a reasonable alternative in the absence of long-term statistical information and given the uncertainty of the actual levels of investment made. The variable cannot necessarily be a measure of the evolution of the production potential of the sector as they do not enter information on productivity. Nor does it allow a comparison of investment levels since the launch of new wells may change substantially in price over time and place. However, assuming that any investment in existing production wells is simply a replacement cost; the analysis of the variation in the number of wells in production can be used as a proxy for net investment.

Records indicate that between 1912 and 1923 there was only one producing well (fig. 3). Between 1924 and 1931, the number of wells increased, reaching a maximum of 5. During the Chaco War there are no records relating to producing wells. In 1936 the number of wells increased again but this time thanks to the intervention of the state. It was not until 1951 that the state could surpass the dozen producing wells. Then around 1955, YPFB once again accelerated investment levels, reaching an average of 25 producing wells.

\footnotetext{
${ }^{9}$ For a quick overview of this process see Zarati (2013). More details are provided in Medinaceli (2012).
} 


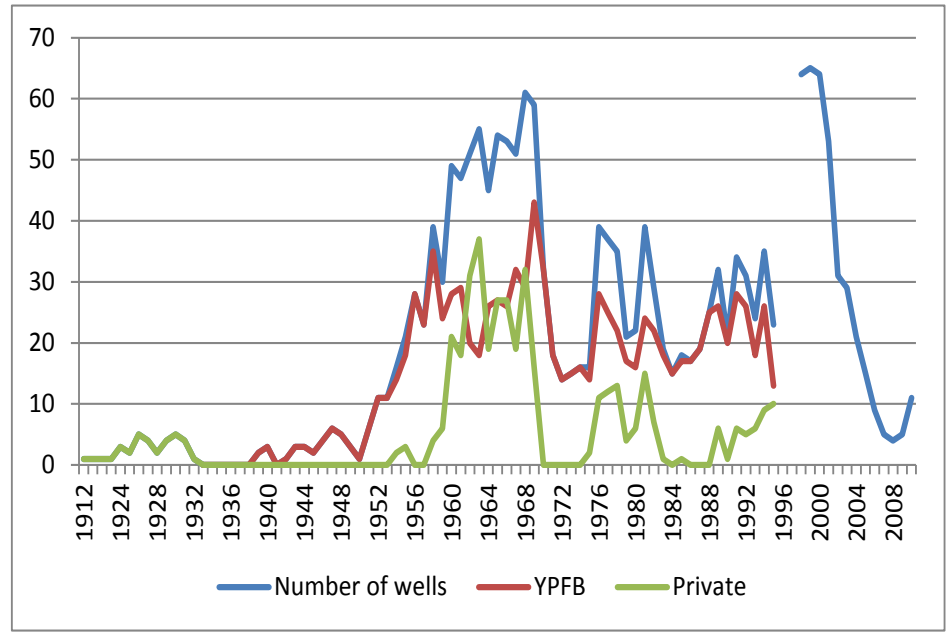

Figure 3: Number of working oil wells by operator (public or private), 1912-2010

Sources: Own elaboration based on Royuela (1996: 226), for years 1925-1996;

Cámara Boliviana de Hidrocarburos (2010: 8), for years 1998-2010

Throughout the 1960s, the number of producing wells increased markedly. On the one hand YPFB maintained on average 27 producing wells. Moreover, thanks to the provision of the new Hydrocarbons Law of 1958, there was increased private investment and thus the number of private sector wells in operation reached an average of 25 . Thus, in the 1960s, there were around 60 wells in production, representing a record for the period.

This amount was drastically reduced as a result of the nationalization of BOGOC (Bolivian Gulf Oil Company) and the end of the wells worked by the private sector. In 1971 YPFB also reduced the number of producing wells. The number of wells in production increased again towards the mid-1970s, a result both of the recovery of previous levels achieved by YPFB and the new Hydrocarbons Law of 1972 which reintroduced the private sector into exploration and production. This time, however, private enterprise in the petroleum industry was more limited: the number of producing wells worked by the private sector between 1975 and 1983 was, on average, only 8 . Thus, with the end of private investment during the early 1980s, the number of wells in production was exclusively related to the activity of YPFB. 
In 1998, through the process of capitalization carried out by the government, private investment again entered the oil industry and the number of working wells was finally able to beat the record reached during the 1960s. The effect, however, was only temporary; a year after the increase, the number of wells in production again decreased steadily and rapidly. The nationalization of hydrocarbons in 2006 could not reverse this falling trend (see below).

Therefore, if one accepts as correct an investment analysis through studying the evolution of the number of wells in production, it is possible to suggest some inferred facts. First, we observe that legislation aimed at attracting private capital was successful: with a couple of years of lag time the number of wells worked by the private sector increased markedly after the passage of these laws (1958, 1972 and 1996) that opened the sector partially or fully to private investment. Secondly, it should be noted that this investment was restricted in time: the number of wells worked by the private sector tended to decrease approximately 10 years after a law allowing "openness" to the private sector was declared. This time limit can have a twofold explanation: the nationalization of private wells (both in 1969 and 2006), but also the maturation of investments and the abandonment of unprofitable wells. Third, with the exception of what happened during the 1950s, it shows that government investment went primarily to maintain the level of previous investments rather than to increase the level of net investment.

Oil production by type of producer (public or private) allows one to analyze how changes in legislation affected the oil and gas sector (fig. 4). The graphical information shows that the first barrels produced in the country were developed entirely by the private sector, notably Standard Oil. In contrast, with the founding of YPFB and its entry into the hydrocarbon market the new company enjoyed a "de facto" monopoly. Among the achievements of this de facto monopoly are two periods that stand out. On the one hand, during the decade of the 1940s there were no large increases in production levels, but some qualitative improvements. ${ }^{10}$ On the other hand, beginning in 1954 , not only were there important qualitative changes, but oil production was able to be increased significantly, allowing the country self-sufficiency

\footnotetext{
${ }^{10}$ These consisted in the establishment of various pipelines throughout the country, the foundation of a refinery in Cochabamba and the beginning of exports to Argentina. See Miranda (1999: 247-250).
} 
in terms of oil. From 1956 through 1968, YPFB oil production remained stable at around 3 million barrels per year, on average.

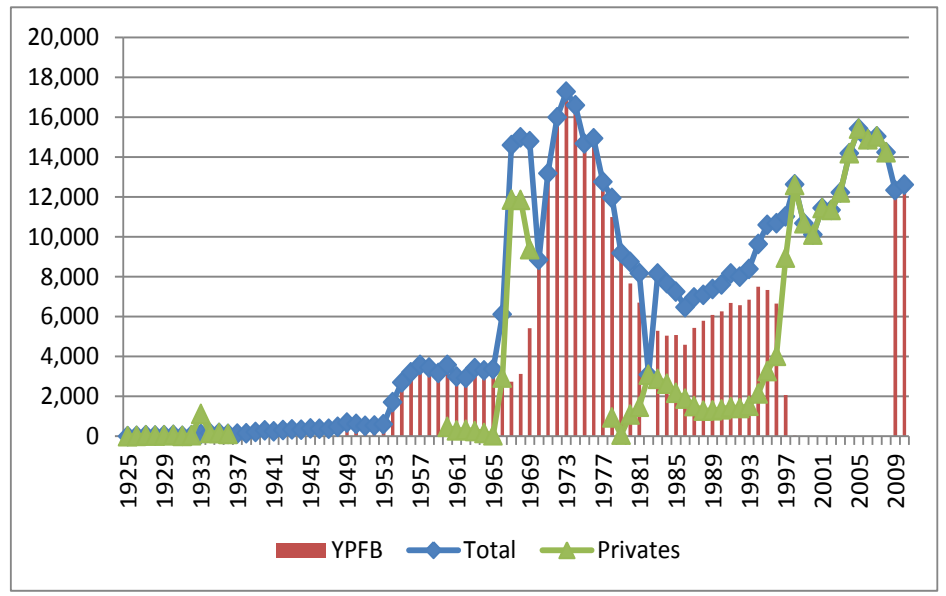

Figure 4: Production of oil in Bolivia in thousands of barrels per year by operator, $1925-2010$

Sources: See fig. 1

We noted above that the Davenport Code was the result of the unsustainability of the currency-driven oil investment scheme through use of mining funds. We also demonstrated that the impact of new legislation on private investment had a more or less positive immediate effect (two years). Although not all investments were commercially successful (Miranda, 1999: 250-252), Figure 4 stresses that the impact on oil production was in fact immediate. However, it was not until 1966 that private production levels achieved those being reached by YPFB. This was the result of the increase generated by the production of BOGOC which grew significantly again in 1967, reaching four times the oil output of YPFB.

With nationalization, YPFB acquired the BOGOC fields. After reaching the record levels achieved in 1973, YPFB oil production tended to decline steadily. The decline was halted by 1982 , but at production levels similar to those achieved before nationalization. Similarly, although by 1989 the production 
of YPFB again increased significantly, the levels achieved were far less than those obtained in the first half of the 1970s.

The reduction and stagnation of YPFB oil production from the second half of the 1970s to the late 1980s was not offset by an increase in private production. Unlike what had happened previously, the opening up of oil exploration to private companies in 1972 did not lead to a significant increase in levels of private production. Although between 1978 and 1994, the statistics recorded seven private companies producing oil, levels of private production stagnated at around 2 million barrels annually.

Therefore, it was not until the legislative changes of the 1990s that private oil production regained its dynamism. After 1994, private company production expanded and their recovery accelerated in 1997 with the start of production of the so-called capitalized companies. From 1998, government records no longer counted the production of YPFB, but show an increase in private production (the so-called contractors and capitalized companies). This, in turn, allowed total production levels by 2005 to approach the historic record levels of the 1970s. Nonetheless, production levels decreased after the nationalization process. ${ }^{11}$

Unlike the case noted in the number of producing wells, it is more difficult to provide some inferred facts on long-term patterns. First, evidence on the success of the opening up of private investment is contradictory. The provisions of these private investment laws allowed a significant increase in oil production on several occasions $(1921,1958,1996)$, but was relatively ineffective on others (1972). Second, the increase in oil production does not appear to be solely the result of private investment; the jump in 1954 was due to strong government commitment to redirect domestic savings from mining to oil production. Third, the nationalizations that occurred appeared to be successful to the extent that they took advantage of previous private investment while maintaining production levels. However, a question arises as to the sustainability of that process. For example, oil production declined significantly from the second half of the 1970s. Also today there is uncertainty about the ability of YPFB to maintain oil production levels such as existed prior to the nationalization of 2006. ${ }^{12}$

\footnotetext{
${ }^{11}$ Moreover, the preliminary evidence available shows that despite an increase in total production during the most recent years (2012-2013), production levels are still below the record levels of the 1970s.

${ }^{12}$ See, for instance, the annual reports of the "Cámara Boliviana de Hidrocarburos" or those by the "Fundación Milenio."
} 
The growth of oil production is important as an indirect indicator of the country's ability to sustain itself without resorting to fuel imports. In this regard, Figure 5 illustrates the evolution of fuels production from 1931 to 1996. ${ }^{13}$ Despite the differences in levels between each of the products analyzed, it is clear there is a common trend. Production was limited until the mid-twentieth century, but increased steadily from 1953. While it slowed in the second half of the 1950s, it accelerated again from the early 1960s. The increased production of oil moved steadily upward until the late 1970s. From then to nearly the mid-1990's, production remained stagnant or, at the least, was unable to reach previously achieved levels.

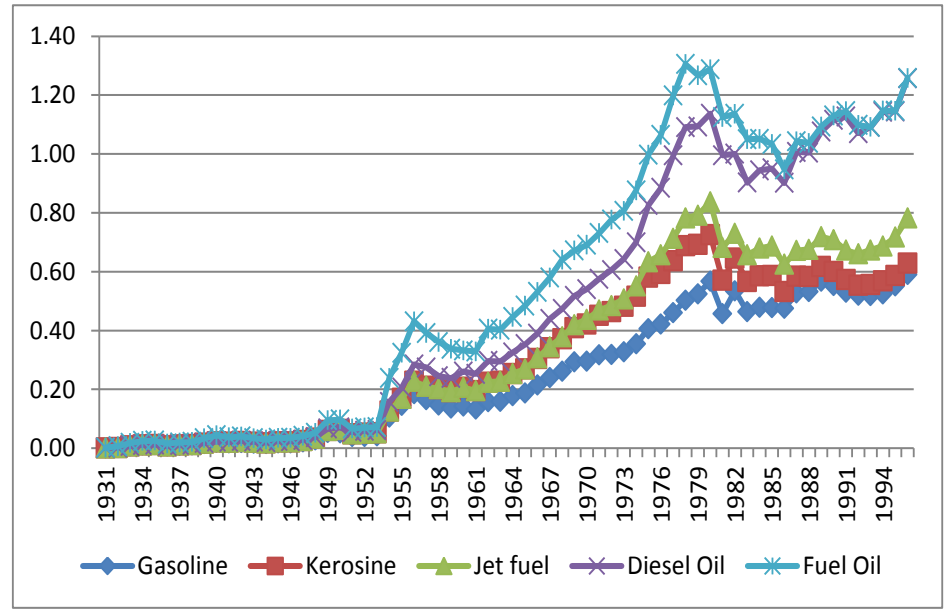

Figure 5: Production of fuels in Bolivia in millions of cubic feet per year, 1931-96 Sources: INE (1997: 38-40)

The effect of this stagnation on sustaining domestic self-sufficiency was quite different. This becomes clear when analyzing the importation sequences of each petroleum product. ${ }^{14}$ Indeed, while imports of fuel oil remained more or less constant, diesel oil imports increased markedly from

\footnotetext{
${ }^{13}$ The analysis stops in 1996 due to certain methodological problems with data reported by YPFB from that year forward.

${ }^{14}$ For this, see BADECEL, http://websie.eclac.cl/badecel/badecel_new/index.html.
} 
1990 onwards and gasoline imports increased during the last few years. Thus, the analysis of import sequences highlights the inability of the country to maintain self-sufficiency in certain products and, once again, beyond its management model, it appears that the Bolivian economy is undergoing structural constraints in its ability to increase oil and fuels production.

The production of natural gas by producer category is another variable that allows us to understand the effects of legislative changes on the hydrocarbon sector (fig. 6). Records begin in 1952 and show that through the 1950s production levels were low. In the 1960s they began to expand slowly, linked with the beginnings of small exports to Argentina. The increase is explained partly by a growing trend in YPFB's production, but mainly by the increase in private production after 1966, specifically by BOGOC. Therefore, as in the case of oil, it can be said that the opening up to private investment led to increased natural gas production.

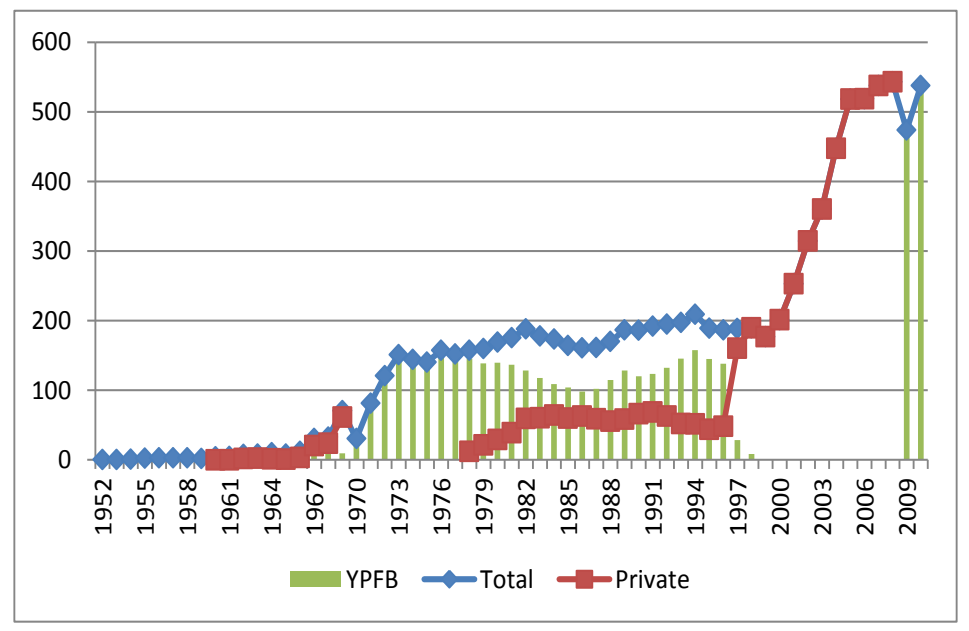

Figure 6: Production of natural gas in Bolivia in billions of cubic feet per year, 1952-2010

Sources: See fig. 2

With the nationalization of BOGOC and thanks to successful negotiations with Gulf Oil and pipeline financers, YPFB was able to take over all these projects. This explains why YPFB was exclusively responsible for the significant increase in natural gas production in the 1970s. Nonetheless, from the late 1970 s to 1986 , natural gas production generated by YPFB tended to decline. 
The legal opening up of access to private companies in 1972 partially offset this process given that private production increased from 1978 to 1982. From that point forward it tended to plateau. Thus, the cycles in the production of YPFB and the short increase in private production explain the modest increase in aggregate production into the mid-1990s.

The evolution of the natural gas sector changed with the initiation of natural gas exports to Brazil. That project dates from 1973 but it was not until the early 1990s that it began to materialize, a result of increased interest by Petrobras and representatives of the Brazilian industry, as well as the Bolivian state's ability to make credible commitments (Miranda, 1999: 260-263). That was based on the passage of a new Hydrocarbons Law and the capitalization of YPFB. This process involved the capitalized companies supplanting YPFB as producers in 1997. During the early period, production by these companies remained at the same levels as those generated by YPFB. The production level of so-called "contractor companies" also remained stable and thus aggregate output changed little. This was the situation until 2000, when natural gas exports to Brazil finally began. From that moment on the natural gas production of private companies expanded exponentially. In aggregate terms this new outlet for Bolivian gas led to a considerable increase in production.

Whereas gas production levels tended to stabilize after the 2006 nationalization, production increased again in 2013, achieving record levels. This last process, however, did not result from the discovery and exploitation of new reserves but from an increased production of the already known reserves - namely the so-called mega campos (mega fields) of San Alberto, Sábalo and Margarita (see Fundación Jubileo, 2013). Therefore, if the Bolivian government is not able to discover new reserves and ultimately replace those that are currently intensely exploited, the long-term sustainability of the gas sector may not be possible.

Furthermore, from a long-term perspective, we note that exports were the engine of growth in natural gas production. This is clear when it is seen, on average, that between 1972 and $199070 \%$ of natural gas production was exported, an index that increased to $80 \%$ in the 2000 s. ${ }^{15}$ Thus, beyond the management model, it appears that the key variable in the production

${ }^{15}$ See INE, Estadísticas petroleras. 
of natural gas was the securing of long term export markets. ${ }^{16}$ In this sense, beyond the statutes of the actual law, equally in the case of exports to Argentina or Brazil, it was the Bolivian state's ability to make credible and sustainable agreements with private actors that was crucial in sustaining this growth.

The analysis of the evolution of taxes contributed directly by the hydrocarbon sector allows a final evaluation of the impact that legislative changes had on this industry. ${ }^{17}$ In the first decades of the twentieth century it was decided that the industry should pay either a royalty and/or pay for the rights to exploitation. Tax legislation tended to change over the years, but due to the relatively low impact those taxes had on the sector, state income produced was minimal. Things began to change in 1929. In that year it was decided that the royalty should be $30 \%, 11 \%$ of which went to benefit the producing regional departments. This measure was ratified in 1938, but this time it was established that $11 \%$ of the total production would be placed in the hands of the producing departments. Thus, along with the founding of YPFB, the government established a higher tax burden on the sector. These legislative changes had little impact on central state finances, but were instrumental in producing income for the departments, particularly Santa Cruz. This pattern was repeated during the decade of the 1950s. In line with strengthening YPFB, and after strong pressure from Santa Cruz, the central government ratified the right of producing departments to a royalty equal to $11 \%$ of oil production.

Things began to change again with the establishment of the Davenport Code of the 1950s. One of the arguments used to justify the nationalization of BOGOC emphasized the deficiencies of this code in relation to tax matters. For example, it pointed out the existence of an extremely complicated calculation in the case of tax on utilities or the lack of clear rules regarding the taxation of natural gas (Miranda, 1999: 250-251). So far it has not been possible to ascertain whether or not the new legislation generated a decline in oil taxes collected by the central state. However, analysis of the royalties paid to the departments shows a decrease between 1958 and $1967 .{ }^{18}$ What is striking is that this reduction occurs not only in real terms, but also in nominal

\footnotetext{
${ }^{16}$ The need for secure markets is explained by the risk inherent in the activity. This risk translates into a high fixed-capital investment for production wells and pipelines.

${ }^{17}$ The following paragraphs are based in Peres-Cajías (2013).

${ }^{18}$ See INE, Estadísticas petroleras.
} 
terms. This last item could be considered proof of the claims of that time that of the stagnation of oil taxes as opposed to higher production levels.

In this sense, after BOGOC's nationalization and compensation, there emerged a new tax framework. This tended to increase the tax burden, benefiting not only departmental treasuries, but also that of the central state. The impact of the move was immediate; tax revenues generated by the hydrocarbon sector between 1971 and 1976 increased considerably and, as a result, hydrocarbon taxes came to constitute a quarter of the central government revenues. Then, however, they began to decrease, both in absolute and relative terms. The drop was particularly marked from 1982 to 1985 .

The tax rules on the sector again changed in a major transformation carried out in 1985. With the establishment of the neoliberal "New Economic Policy" and the concurrent crisis in the mining sector, the state decided to increase the tax burden on the hydrocarbon sector through various new additional taxes. These fiscal reforms not only resulted in the major growth in hydrocarbon taxes, but also saw tax collections exceed pre-crisis levels. It is striking, however, that tax revenues hardly changed from then until 2003. This fiscal revenue stability was due to various legislative changes and occurred despite a major increase in gas production levels and in profits for the oil companies. This stability allows us to understand the recurrence of complaints about the shortcomings of the taxation schemes associated with these laws that opened up the sector to private investment. These complaints, in turn, were what prompted the formulation of the new Hydrocarbons Law of 2005. With this new law, the hydrocarbon tax again grew considerably. These levels were maintained through the "nationalization" of 2006. Thanks to this increase in hydrocarbon taxes, Bolivia state income has reached levels never before seen in its history.

Hence, with a long-term perspective two evident facts are inferred. On one hand, it is noted that oil privatization legislation reduced or at most maintained tax pressure on the sector to the detriment of state finances. On the other hand, it is clear that the processes of government intervention in the sector were accompanied by imposing a higher tax burden on the sector. In the 1930s the biggest beneficiaries were the departmental treasuries. In the 1970s and 2000s, again it was the departmental treasuries that benefited, but also this time central state income expanded very significantly. 


\section{Conclusions}

Previously we identified three processes of intensification of direct state intervention in the hydrocarbon sector. A common claim to the three processes is the demand - fuelled by the ideological tendency by some Bolivian politicians as well as pressure from the people - that the resources generated by the hydrocarbon sector should benefit more the nation and less outside investors. From this perspective, the process of nationalization can be considered a success. Thanks to these measures, the state became the owner of previous investments made by private companies (in the first and second nationalization) and could substantially increase the tax contributions of the sector (in the third nationalization).

However, if nationalizations were successful, why is it possible to identify four processes which opened up investments for private capital? Beyond ideological attitudes towards the importance of private participation in the economy, it is clear that the need for increased investment to develop the deposits of hydrocarbon resources could not be fully funded by the Bolivian state. The four laws mentioned show that the state realized that domestic savings were insufficient to develop and sustain the hydrocarbon sector. Thus, it appears that nationalizations in Bolivia have been successful so far as they took advantage of previous investment which permitted sustained increases in the production of oil and natural gas. This underscores the success of the legislation for "opening up" access (by this we mean the government's opening up of the hydrocarbon sector to private investment) in its main objective, which was in attracting private investment.

This analysis of the relative success of the different legal frameworks permits us to understand why the state has been changing from one scheme to another over time. However, it does not allow us to understand why this scheme could succeed with such regularity. Several explanations are possible. First of all, it could the case that changes in legislation were related with the ideological swings of those authorities that managed the Bolivian government. Secondly, it could also be the case that foreign companies have continuously returned to Bolivia because the country's reputation has not been entirely spoiled. Indeed, the country reached an agreement on compensation with Standard Oil with which it fully complied. Also it achieved an agreement with Gulf Oil that was also fully met. As for the current nationalization process, it is difficult to identify any real tensions between private companies and the state. Thirdly, beyond its reputation, it could also be the case that the Bolivian state could attract foreign investment because it recognized the jurisdiction of international tribunals for the settlement of 
disputes (the Davenport Code and Petroleum Law of 1996). Finally, it is also conceivable that external companies are willing to take the risk because the expected return is considerable. In this context, the permanence of the companies after the nationalization of 1969 and 2006 could be related to changes in the world oil market and its impact on international prices.

The above arguments may be generalized to other experiences. In Bolivia, however, there is a feature that cannot be ignored - the economic and geopolitical interests of Argentina and Brazil in Bolivian hydrocarbons. These interests were expressed in bilateral agreements signed by Bolivia with Brazil and Argentina in the late 1930s. Moreover, the continued support of the Argentine YPF was instrumental in strengthening YPFB in the 1940s. In the same vein, without the Argentine interest in Bolivian gas in the 1960s, it is impossible to see how the export project would have been initiated by BOGOC, but funded by YPFB. Finally, the search by Brazil to establish itself as the regional leader in South America certainly facilitated the renegotiation of contracts with Petrobras during the last nationalization process.

\section{Works cited}

ALMARAZ, Sergio. 1958. Petróleo en Bolivia. La Paz: Editorial Juventud.

CÁMARA BOLIVIANA DE HIDROCARBUROS. 2010. Cifras 2010 en perspectivas. La Paz: $\mathrm{CBH}$.

CAPRA, Katherine, Alberto Chong, Mauricio Garrón, Florencio López-de-Silanes y Carlos Machicado, eds. 2005. "Privatization and Firm Performance in Bolivia." Privatization in Latin America: Myths and Reality. Alberto Chong and Alberto Lopez-de-Silanes, eds. Palo Alto, CA: Stanford University Press. $117-44$.

COLLE, Elio M.A. 1935. El drama del Paraguay. Buenos Aires: Editorial Claridad. Delegación Presidencial para la Revisión y Mejora de la Capitalización. 2004.

Diez años de la capitalización, luces y sombras [seminario internacional, La Paz, 13 de octubre de 2004].

FUNDACIÓN JUBILEO. 2013. "Situación de los Hidrocarburos en Bolivia." Serie de Debate Público 27: 1-16.

GÓMEZ D'ANGELO, Walter. 1978. La minería en el desarrollo económico de Bolivia. 1900-1970. La Paz-Cochabamba: Los Amigos del Libro. 
GREBE, Horst and Chávez, Juan Carlos. 1998. Las reformas estructurales en Bolivia. La Paz: Fundación Milenio.

HERRANZ-LONCÁN, Alfonso and José Alejandro Peres-Cajías. 2013. "Tracing the reversal of fortune in the Americas: Bolivia GDP per capita since the midnineteenth century." Paper presented at the European Historical Economics Society Conference. [http://www.ehes.org/Herranz.pdf] página descargada el 25 de agosto de 2014.

INE. 1997. Estadísticas económicas de la actividad petrolera. La Paz: INE.

LÓPEZ, Pedro. 1922. Bolivia y el petróleo. La Paz.

LOZA, León. 1939. Bolivia, el petróleo y la Standard Oil Company (Publicación No. 3 de Yacimientos Petrolíferos Fiscales Bolivianos). Sucre: Editorial Charcas.

MAROF, Tristan. 1934. La tragedia del altiplano. Buenos Aires: Editorial Claridad. MEDINACELI, Mauricio. 2012. "El sector hidrocarburos en Bolivia." Policy Paper FES-Bolivia 02/12: 1-33.

[http://www.researchgate.net/publication/259754579_El_sector_hidrocar buros_en_Bolivia___Policy_Paper] página descargada el 25 de agosto de 2014.

MIRANDA, Carlos. 1999. "Petróleo. Del descubrimiento petrolífero a la explosión del gas." Bolivia en el siglo XX. La formación de la Bolivia contemporánea. Fernando Campero, ed. La Paz: Harvard Club de Bolivia.

MONTENEGRO, Carlos. 1938. Frente al derecho del estado, el oro de la Standard Oil (el petróleo, sangre de Bolivia). La Paz: Editorial Trabajo.

MUÑOZ REYES, Jorge. 1937. La caducidad de las concesiones otorgadas a The Standard Oil Company of Bolivia (Cuartillas Informativas No. 5) La Paz: Departamento Nacional de Propaganda Socialista.

NACIONES UNIDAS. 1958. El desarrollo económico de Bolivia. México: Naciones Unidas.

PERES-CAJÍAS, José Alejandro. 2013. Bolivian Public Finances, 1882-2007.

Challenges and Restrictions of State Intervention in a Small, Multiethnic and Revolutionary Economy. Diss. University of Barcelona.

ROYUELA, Carlos. 1996. Cien años de hidrocarburos en Bolivia. La PazCochabamba: Los Amigos del Libro.

SCHURZ, W.L. 1921. Bolivia: A Commercial and Industrial Handbook. Washington, D.C.: Department of Commerce.

SETARO, Ricardo. 1936. Secretos de estado mayor. Buenos Aires: Editorial Claridad. 
ZARATI, Francesco. 2013. "La nacionalización de los hidrocarburos en Bolivia: luces y sombras". NOVAMERICA 139 (julio-sept.): 60-63.

ZONDAG, Cornelius. 1966. The Bolivian Economy, 1952-65: The Revolution and its Aftermath. New York: Praeger.

\section{(cc) $\mathrm{EY}$}

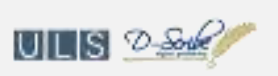

New articles in this journal are licensed under a Creative Commons Attribution 4.0 United States License.

This journal is published by the University Library System of the University of Pittsburgh as part of its D-Scribe Digital Publishing Program, and is cosponsored by the University of Pittsburgh Press. 